\title{
The Global Marketplace and the Privatisation of Security
}

\section{Jeffrey Isima}

\begin{abstract}
The privatisation of security in the age of globalisation raises crucial concerns for global governance and development. Key among these are the impacts on the structures of poverty and inequality, and how these twin development issues shape global security privatisation. Equally important are the structural limits on public policy imposed by the promotion of the market as a powerful alternative mechanism for security provisioning. These concerns have become more urgent as the dominant neoliberal security governance paradigm has tended to avoid questions relating to poverty, social inequality and the dire condition of those who live on the margins of state protection. This calls for innovative policy changes for transforming security institutions and practices in a way that promotes security, not just for state officials and the wealthy, but most importantly, for the poor. This article attempts to explore these core development concerns in relation to the increasing outsourcing of security to non-state actors and how state actors, as leading agents of development, can protect and promote the wellbeing of vulnerable populations within the global market order.
\end{abstract}

\section{Introduction}

The increasing dominance of the marketplace in security provisioning has been closely associated with the current process of neoliberal

globalisation. This process, which picked up with an unprecedented momentum at the turn of the 1980s, has seen a continuous restructuring of global governance in such a way that the state is no longer the only important actor in the quest for development. A key component of this restructuring has been the increasing privatisation of services, which were traditionally delivered publicly, by a plethora of non-state actors. Yet states, conversely, have shaped the process of globalisation in the historical search for development through deliberate national policies. The ongoing global financial and economic crisis and the interventionist response of US and European governments is a living testament to this. The current global wave of security privatisation, therefore, needs to be explored and evaluated in the broader context of development in which the globalising world order has imposed a complexity of constraints on and provided opportunities for public policy in the quest for equitable security. This article focuses on the implications of security privatisation for poverty and inequality. Also considered is the appropriate role of state actors, as leading agents of development, within the structural limits of globalisation.

The searches for security and the pursuit of development have always gone hand-in-hand. Although, historically, these two fields had been artificially separated in scholarship, we are increasingly seeing their remarriage over the last decade or so. There is now an increasing awareness among the very forces that previously promoted international development that security is not just a development issue but lies at the core of development. This conviction is so strong that it is now almost generally accepted that there can be no development without security (DFID 2002; World Bank 1999). Long before the age of globalisation, inter-state war and conflict were always driven by development objectives. States went to war with each other mainly because they, or their elites, sought to advance their national development interests at the international arena and they were confronted with incompatible development 
interests of other states. In cases when (national) security was pursued without factoring in the economic implications, it has brought national and global development woes, as seen in the Vietnam War and the subsequent fiscal crisis of the early 1970s in the USA (Payne 2005: 24-5). We are now seeing the crisis of financial stability in the USA, and in the rest of the world, closely following behind the infamous 2003 invasion of Iraq.

It is within this interconnectedness of security and development that the privatisation of security is assessed in this article. It argues that although the state has undergone - and is still undergoing - profound transformation in response to structural changes brought about by the process of globalisation, it has remained the principal agency for development and security among other new and emerging actors. Also, the privatisation of security is considered here in its broadest conception, embracing security provided by both corporate and informal actors.

Private security is, admittedly, a phenomenon that has coexisted with the evolution of the modern state. However, the sheer scale and the global reach of the ongoing wind of security privatisation has prioritised it in public policy and academic inquiry. Yet, while security privatisation has generated enormous literature, particularly since the $1990 \mathrm{~s}$, its link with the issues of development, poverty and inequality, crucial in grappling with the dilemmas of human security, has not been sufficiently established, let alone fully understood. In this chapter, an attempt is made to explore these core development concerns in relation to the increased outsourcing of security to non-state actors and what state actors can do to secure and promote the wellbeing of vulnerable populations within the global market order.

This article relies on theoretical analysis based on instances from different parts of the world, although most references are to developments in Africa. It is hoped that its analysis will contribute significantly to the setting of a robust agenda of empirical and participatory inquiry that would generate policy-relevant options for transforming security institutions and practices in a way that promotes security, not just for state officials and the wealthy, but most importantly, for the poor.

\section{$2 \mathrm{~A}$ brief survey of the literature}

Private security arrangements are not a new phenomenon. Indeed security has long been provided privately even in some of the oldest states. For example, the modern police did not emerge in the UK until 1829, and before then, policing was provided through quasi-official agencies (Abrahamsen and Williams 2007: 133). In the USA, vigilantism was a major instrument for social ordering until the beginning of the twentieth century (Brown 1976). In addition, Zamparelli (1999) reminds us that the US military has a long tradition of relying on private security contractors, dating back to the Vietnam War era. It is also known that the modern private security industry dates back to the 1950s in the USA and 1935 in the UK (Abrahamsen and Williams 2007: 133), and that private guards in the USA have been three times more in number than the public police since the 1970s (Rosky 2004: 987). Yet, in spite of this history, we are witnessing an unprecedented expansion of security privatisation worldwide, with a scale and impact that cannot be treated as normal.

Schreier and Caparini (2005: 44) have captured some of the thorniest concerns around the activities of modern private military and security companies (PMSCs). Research on them has tended to focus on the debate around the controversial relationship between PMSCs and mercenary activities, while informal security actors as well as development issues of poverty and inequality have been marginalised. The UN (2007), for instance, asserted a close link between PMSGs and mercenaries, while some notable analysts on the subject see these companies as the latter-day reincarnation of the old mercenaries in corporate garb. Defined as the 'new mercenaries' and 'corporate warriors', which need to be reined in (Singer 2003; Mockler 1987; Musah and Fayemi 2002), PMSCs are considered as a force for destabilisation in conflict zones and dangerously undermining human security generally. Particularly, they are observed as agents of arms proliferation (Makki et al. 1995: 1-2). However, more recently, the presumed link with mercenary activities has been perceived as more tenuous, and analyses appear to be shifting towards the need to separate the two in order to properly regulate the security market while maintaining and enforcing the international ban on mercenary activities (FCO 2002; Holmqvist 2005; Gumedze 
2008). Making this separation has, however, required a clear categorisation of the various actors in the security market, and this has resulted in a lingering definitional conundrum. ${ }^{1}$ While the search for definition and categorisation continues, a few inquiries have been made on the political economy of security privatisation, which have some bearing on development.

Avant (2005) has sought to challenge the prevailing trend to preferring the market over the state in determining the employment of force around the world. In so doing, she helped highlight some of the difficult trade-offs the market has imposed on the scope of control by the state. Another important analysis has examined the role of private military companies associated with powerful 'oil-thirsty countries' and multinational corporations in post-Cold War wars that are linked with the international political economy of oil in different parts of the world (Kaldor et al. 2007). In Africa, combatactive military companies have been linked to the extractive industry and multinational corporations operating in conflict and unstable countries with abundant mineral resources (Creutz 2006: 39), through which these corporate actors have become involved in resource wars (Shannon 2000: 105) and in facilitating international trade in conflict goods (Spear 2006).

These are useful efforts, which flag the seriousness of broader issues of political economy that attend the industry. Yet, as Abrahamsen and Williams (2007: 131) indicate, such analyses tend to concentrate on the 'combat active private military companies' and that we need to shift attention to other private actors. This is valid, although it may be useful to add quickly that some of the private security actors involved, closely or distantly, in resource wars are not necessarily hard-core military companies, and that the private security industry is very slippery, allowing for easy transmutation in the relationship between the activities of multinational businesses, the seemingly benign security companies and the combat active military versions in the cast of the Executive Outcomes. One only has to take a closer look at the conflict in the oil-rich Niger Delta in Nigeria or consider the composition of some of the actors involved in the failed bid to unseat the government in Equatorial Guinea in 2004, to appreciate this complexity.

Apart from their narrow focus, what is noteworthy about the studies on security privatisation is their failure for the most part to touch upon the issues of development, poverty and inequality. Sadly, very few tentative studies link the private security market with conditions of inequality and marginality. In a recent examination of the industry in Uganda, Kirunda (2008: 1) observes that the security market promotes social stratification as companies operate exclusively in urban centres and avoid outlying areas where operational costs are prohibitive. This logic also operates in Africa's major cities where crime shifts to the inner cities as richer neighbourhoods are protected by commercial security. This study highlights the spatial distribution of security as a commodity and forces us to think about the security of lowincome locations and regions that are not attractive to markets. Also, given that the majority of people living in rural and outlying settings are, generally speaking, poorer than those in the capitals and cities in Africa and elsewhere, there is a need to inquire more into the place of poverty and inequality in the market for security. This becomes more urgent when one considers that public policing in most of Africa is also largely urban in focus (Hills 2000), and that the market might exacerbate this inequality.

This leads to the second important concern of this article: the security self-help mechanisms in the marginal areas of our globalising market order. Much literature has been generated on the subject of vigilantism and other means of selfhelp protection, and it is well known that where the state does not adequately protect the poor and their livelihoods, they have always relied on security provided by informal actors (Scharf and Nina 2001). What is needed is to locate the informal security sector within the discourses of equitable security governance and the globalising market for security. A seminal effort towards establishing this link has been made by Ero (2000: 26), who sees vigilantes and local militias as cheap, community-based elements of the security market in search for security outside formal state structures. Even though the issues of poverty and inequality are not explicitly spelt out, these insights draw attention to the marginality of the informal security sector and 
its occupants and constitute a crucial starting point for analysis.

3 Security governance in the age of globalisation

There is no doubt that we now live in a world where our daily social experiences are being shaped by powerful global dynamics which are constantly unfolding. This process of globalisation involves, essentially, what has been described as the widening, deepening and speeding up of worldwide interconnectedness in all aspects of contemporary social life (Held et al. 1999: 2), and this includes our security. It is creating a structural order in which the state is not always necessarily the single most important actor. Although security has been provided privately before and after the emergence of the modern state, the golden age of the state witnessed an intensive quest by national elites for centralisation and public monopoly of the means of legitimate violence for security purposes. Security, therefore, increasingly became a public good managed by sovereign states in a world order, in which the pursuit of public monopoly of security was a dominant state strategy worldwide.

However, that world order was also characterised by inequality such that the degree to which the state succeeded in the centralisation and monopolisation of security varied from country to country, depending to a very large extent on national material capabilities. This inequality was well captured by early Development Studies with the now exhausted 'North-South', 'developed-developing countries' intellectual bifurcation of the world economic order. ${ }^{2}$

Managed by the hegemonic power of the USA, and supported by the rich countries of Western Europe and Japan, this order was also characterised by the construction of 'national security states' in rich countries and the proliferation of localised wars and the destabilisation of leftist regimes in new states (Payne 2005: 24). In effect, the inequality of the international economic order was reflected in national security capabilities. However, even though the public monopoly of legitimate violence was not conclusively attained anywhere, the state rose to be the central manager of security.

The transition to a global world order, traced to the end of US international hegemony as a result of the financial crisis in that country from the turn of the 1970s, and the associated world economic crisis of the 1980s, undoubtedly set back the centrality of the state in the overall pursuit of development. ${ }^{3}$ Indeed, the privatisation of security represents an important aspect of this setback as the drive towards the public monopoly of legitimate violence was overtaken by globalisation in which the market has emerged as a powerful alternative mechanism for service delivery and imposed structural limits to the scope of state policy. In this context, the ascendancy of PMSCs and other private actors in security governance has come to be represented as an 'inescapable' reality of globalisation which cannot be gainsaid, but one with which the state has to live and negotiate the shifting terms of authority. This thinking has come to impose a neoliberal paradigm of security governance, which entrenches global inequality and endangers efforts towards equitable security.

This paradigm itself, not surprisingly, stemmed from the early triumphalist interpretation of globalisation. Presented by those whom Held $e t$ al. (1999) refer to as the 'hyperglobalisers', this interpretation sees globalisation as an unstoppable one-way traffic embodying powerful global forces, which shape all aspects of our social life in a way that we cannot resist. This neoliberal view was championed by notable scholars, particularly Ohmae (1995), who were quick to celebrate 'the triumph of the market over the state', and hastily announced the 'end of the state', which was seen as retreating so precipitously that it has ceased to be analytically relevant. This view exaggerates the influence of structure over agency and sees globalisation as deterministic. One of the most dangerous fallouts of accepting globalisation as such, as has been pointedly observed by Hay and Marsh (2000), is that it can be instrumentalised by state elites to promote acquiescence in security policies and practices that favour their personal interests. It is also insensitive to the issues of social inequality accompanying globalisation, and it is little wonder that the current paradigm of security governance has tended to single out the commercial component of security privatisation at the expense of informal actors, thus largely avoiding questions relating to poverty and global inequality in security governance. 
A brief examination of the normative structure of globalisation is appropriate in order to clearly understand the linkages of security privatisation and social inequality. First, globalisation is hardly as sacrosanct as we are being compelled to accept. Second, a view that is increasingly being imposed on our thinking is one which sees contemporary security governance as a 'network' operating without a clearly defined centre but rather composed of interlinked nodes, the state being one of such nodes. The proliferation of private security actors is thus taken as part of this new 'networked security governance' in which the state should no longer be conceived as the central actor but one whose position within the network varies according to time and space (Johnston and Shearing 2003; Dupont 2004; Abrahamsen and Williams 2007). The danger of such thinking (and of the developments behind it) is that we may no longer need a final arbiter in the matters of security in our national societies. It also implies that state policy should give way to other mechanisms for security delivery.

We cannot deny the ongoing construction of a global system in which nearly all parts of the world are increasingly being interlinked. Yet we also need to note that this new global system represents only a particular variant of globalisation that has been rightly branded as 'neoliberal globalisation' (Scholte 2000). Another critical assessment describes it as a 'globalising liberal political economy' and questioned the 'immutability' representation by arguing that it is possible for this order to be turned over into another variant of globalisation in the course of time or even that globalisation itself will be rolled back (Payne 2005: 31-2). Globalisation, therefore, did not just drop out of nowhere, but rather it marks the ascendancy and climaxing of neoliberal thinking and policies, consciously promoted by powerful countries through international financial institutions as their preferred alternative route to development. Williamson (1993) has described how the Reagan and Thatcher administrations in the USA and UK, respectively, as well as the International Monetary Fund (IMF) and the World Bank, launched and shaped the triumph of the neoliberal order through the so-called 'Washington Consensus'. The current 'bail-out' interventions by the state in the USA and
Western Europe to rescue some of the biggest banks and financial houses in the world from the ongoing global financial crisis reminds us of the influence of state agency in shaping globalisation.

The current global economic crisis also shows that the current global order is not a 'given' but rather a successful but temporary projection and global expansion of national power and development objectives by a few countries. As aptly captured by Hurrell and Woods (1995: 447), this neoliberal version of globalisation is driven by structural inequality among states in terms of global ideology, access to and control of international institutions, transnational private actors as well as national material capability. These inequalities need to be reflected upon when examining the current privatisation of security and its implications for development.

This is importantly so, not only at the global level but also at the local, where informal security provision starkly reveals the dire condition of those who lack the ability to purchase security and who live on the margins of state protection. The notion of a new model of security governance operating as an all-inclusive network in which various actors are linked and work together for a common goal hardly applies in many societies or parts of society caught between the state and the market. In such areas, the network only operates as a dubious and an exclusive contract between state and commercial elites. Vigilantes, neighbourhood watches and civil militias are, in most cases, excluded from such governance networks. Where they have any links to the state, such links only developed as an emergency elite response to crisis, such as the state collaboration with the Kamajor against the rebel Revolutionary United Front in Sierra Leone during that country's recent civil war. In most cases, any such linkages operate informally through 'elite capture' and 'political instrumentalisation' against domestic opponents. Rather, it is the failure to integrate those left out by the state and market into security governance that has permitted their criminalisation or metamorphosis into agents of political violence.

\section{Conclusion: illiberal markets, security and inequality}

This last example also calls our attention to the ever-present menace of market failure and the primacy of the state in a globalising neoliberal 
order which promotes the market as the main mechanism for shaping major social and political decisions, including security decisions. Security is a crucial dimension of social life for the unemployed or underemployed and is an area where the failure of the market needs to be addressed.

The relationship between globalisation and global inequality has remained a very controversial issue. It has generated an ongoing academic debate, which may not be resolved quickly (Wade and Wolf 2002). However, while the debate rages on, the privatisation of security continues to expand in close association with global inequality of access to security and justice. The globalisation of markets itself is characterised by contradictions in which, as Hoogvelt (1997) rightly observes, some societies are increasingly being integrated while others are being marginalised from the mainstream of economic prosperity. The coexistence of the commercial and informal sectors of security demonstrates a key aspect of these contradictions in which the more wealthy segments of society are protected through the market, while the poorer rural dwellers and those who live in the squalor of inner cities are left to their own devices.

In this sense, it can be seen that while the market system promises to be free, in reality, it fosters injustice and fails to promote equal opportunity for all, hence the use of 'illiberal markets' (Rothkopf 2008: 63). The informal security sector does not provide sustainable security, being haphazard and vulnerable to elite capture, politicisation or criminalisation, as has occurred in such places as Nigeria, South Africa and the Philippines (Isima 2007: 230-47;

\section{Notes}

1 For most existing typologies and the problems of categorisation, see Schreier and Caparini (2005: 33-43).

2 This bifurcation has been challenged for its gross inadequacy to capture the complexities
Kowalewski 1991), and therefore cannot be ignored. Moreover, informal security operates within communities through an organic relationship, which state security forces often lack, not least because of their colonial roots. Bringing in the informal is therefore the beginning of wisdom for security governance in poor countries where both state and market have failed to provide adequate security. In such contexts, there is a need to rethink the entire neoliberal conception of the 'security sector'. This may start with the mapping of informal security forces across the globe and their relationship to global inequality as well as their place in security governance.

Fundamental rethinking is needed on the role of the state in security governance, based on the recognition that states can and do shape the direction of privatisation, particularly in the field of security. The goal of equitable security must be seen as a component of national development strategies, and the state has to assume central responsibility (of course within the framework of sound democratic principles) in protecting poor communities.

Such rethinking also, however, needs to recognise the structural inequalities of power and wealth which impose limitations on the capacity of developing countries to pursue and deliver to their citizens their preferred development strategies. It means such assessment has to take place within the context of the wider global order in order to identify the mechanisms available to national actors for adjusting the objectives of their national development strategies in ways that supports the goal of equitable security.

of actual contemporary international politics of coalition building and dismissed as hegemonic representation. See Payne (2005: 231-46) and Bilgin and Morton (2002).

3 See Payne (2005: 24-6) for detailed accounts of these developments. 


\section{References}

Abrahamsen, R. and Williams, M.C. (2007)

'Introduction: The Privatisation and Globalisation of Security in Africa', International Relations 2.2

Avant, D.D. (2005) The Market for Force: The Consequences of Privatizing Security, New York: Cambridge University Press

Bilgin, P. and Morton, A.A. (2002) 'Historicising Representations of "Failed States": Beyond the Cold War Annexation of the Social Sciences?', Third World Quarterly 23.1: 55-80

Brown, R.M. (1976) 'The History of Vigilantism in America', in H.J. Rosenbaum and P.C. Sedeberg (eds), Vigilante Politics, Philadelphia, PA: University of Pennsylvania Press

Creutz, K. (2006) Transnational Privatised Security and the International Protection of Human Rights, Helsinki: The Eric Castrén Institute of International Law and Human Rights

DFID (Department for International Development) (2002) Understanding and Supporting Security Sector Reform, London: DFID

Dupont, B. (2004) 'Security in the Age of Networks', Policing and Society 14: 76-91

Ero, C. (2000) 'Vigilantes, Civil Defence Forces and Militia Groups: The Other Side of the Privatisation of Security in Africa', Conflict Trends, June

FCO (UK Foreign and Commonwealth Office) (2002) Private Military Companies: Options for Regulation, London: The Stationery Office

Gumedze, S. (2008) 'Pouring Old Wine into New Bottles? The Debate around Mercenaries and Private Military and Security Companies', in

S. Gumedze (ed.), Elimination of Mercenarism in Africa: A Need for a New Continental Approach, ISS Monograph Series, No. 147, July

Hay, C. and Marsh, D. (eds) (2000) Demystifying Globalisation, Basingstoke: Palgrave Macmillan

Held, D.; McGrew, A.; Goldblatt, D. and Perraton, J. (1999) Global Transformations:

Politics, Economics and Culture, Cambridge: Polity Press

Hills, Alice (2000) Policing Africa: Internal Security and the Limits of Liberalisation, Boulder: Lynne Rienner

Holmqvist, C. (2005) 'Private Security Companies: The Case for Regulation', SIPRI Policy Paper 9, January

Hoogvelt, A. (1997) Globalisation and the Postcolonial World: The New Political Economy of Development, London: Macmillan
Hurrell, A. and Woods, N. (1995) 'Globalisation and Inequality', Millennium: Journal of International Studies 24.3: 447-70

Isima, J. (2007) 'Demilitarisation, Informal Security Forces and Public (In)security in Africa: Nigeria and South Africa Compared', unpublished $\mathrm{PhD}$ thesis, Shrivenham: Cranfield University

Johnston, L. and Shearing, C. (2003) Governing Security: Explorations in Policing and Justice, London: Routledge

Kaldor, M.; Terry, L.K. and Yahia, S. (eds) (2007) Oil Wars, London: Pluto Press

Kirunda, S.W. (2008) 'Private and Public Security in Uganda: Country Series', in S. Gumedze (ed.), The Private Security Sector in Africa, ISS Monograph Series, No. 146, July

Kowalewski, David (1991) 'Cultism, Insurgency and Vigilantism in the Philippines', Sociological Analysis 52: 241-53

Makki, S.; Meek, S.; Musah, A.; Crowley, M. and Lilly, D. (1995) 'Private Military Companies and the Proliferation of Small Arms: Regulating Actors', Biting the Bullet Briefing 10, BASIC, International Alert and Safeworld

Mockler, A. (1987) The New Mercenaries, New York: Paragon House

Musah, A-F. and Fayemi, K. (eds) (2002) Mercenaries: An African Security Dilemma, London: Pluto Press

Ohmae, K. (1995) The End of the Nation State, New York: Free Press

Payne, Anthony (2005) The Global Politics of Unequal Development, Basingstoke: Palgrave Macmillan

Rosky, C.J. (2004) 'Force, Inc: The Privatisation of Punishment, Policing, and Military Force in Liberal States', Connecticut Law Review 36: 879-1032

Rothkopf, D. (2008) Superclass: The Global Power Elite and the World they are Making, New York: Farrar, Straus and Giroux

Scharf, W. and Nina, D. (2001) The Other Law: NonState Ordering in South Africa, Cape Town: Juta Scholte, J.A. (2000) Globalisation: A Critical Introduction, Basingstoke: Palgrave Macmillan

Schreier, F. and Caparini, M. (2005) 'Privatising Security: Law, Practice and Governance of Private Military and Security Companies', Geneva Centre for the Democratic Control of Armed Forces (DCAF), Occasional Paper 6, March

Shannon, U. (2000) 'Human Security and the Rise of Private Armies', New Political Science 22.1: 103-15 
Singer, P.W. (2003) Corporate Warriors: The Rise of the Privatized Military Industry, Ithaca: Cornell University Press

Spear, J. (2006) 'Market Forces: The Political Economy of Private Military Companies', Fafo Report 531, Oslo

United Nations General Assembly (2007) 'Resolution on the Use of Mercenaries as a Means of Violating Human Rights and Impeding the Exercise of the Right of Peoples to Self-Determination', $A / R E S / 62 / 145$, adopted during the 62 nd session
Wade, R. and Wolf, M. (2002) 'Prospect Debate: Are Global Poverty and Inequality Getting Worse?', Prospect, March: 16-21

Williamson, J. (1993) 'Democracy and the Washington Consensus', World Development 21.8: 329-36

World Bank (1999) Security, Poverty Reduction and Sustainable Development: Challenges for the New Millennium, Washington DC

Zamparelli, S. (Col.) (1999) 'Contractors on the Battlefield: What Have We Signed Up For?', Air Force Journal of Logistics 23.3: 11, Autumn 